\title{
Consumers and Credit Disclosures: Credit Cards and Credit Insurance
}

Thomas A. Durkin, of the Board's Division of Research and Statistics, prepared this article.

Over the past three decades, much of the federal consumer-protection legislation for credit has required that certain items of information be disclosed to consumers in mandatory formats at specified times. The most prominent legislation in this area is the Truth in Lending Act. Provisions of the original Truth in Lending Act, enacted as Title I of the Consumer Credit Protection Act in 1968, were extensive and detailed. Since then the act has been amended and expanded many times as markets and needs have changed.

Under the original act, the Federal Reserve has the responsibility for writing the implementing rules, which it has carried out with its Regulation $Z$. Because this law is so critical for federal consumerprotection policy in the credit area and because it imposes significant compliance costs on creditors, questions have been raised about its effects on consumers' understanding and behavior.

Assessing the direct effects of disclosure legislation in these areas is difficult. For example, an apparent increase in consumers' understanding of credit matters might be explained by improved disclosure laws, but it might also be explained by advances in education, more widespread and frequent use of credit, or by more-effective solicitations for credit, advertisements, and publications that are not specifically tied to disclosure requirements.

Regarding consumer behavior, some consumers may use less credit after the introduction of expanded disclosures if the required information persuades them that credit is expensive. Others may not change their use of credit at all or might even increase their credit use if the required disclosures either confirm their previous view that credit is affordable or increase their confidence that using credit is a desirable option.

In terms of competition, knowing what conditions might otherwise have prevailed in the marketplace in the absence of required disclosures is not possible. And many other factors affect competition, including the number and size of competitors, production costs, and the information conditions prevailing when the disclosure rules are implemented.

The Congress well understood the difficulty of predicting specific outcomes when it passed Truth in Lending. Rather than suggesting that the purpose of the act was to change markets or consumer behavior in some precise manner, the Congress instead stated less specifically that the act's intent was to improve information conditions generally so that consumers could avoid being "uninformed." Section 102 of the act states, "It is the purpose of this title to assure a meaningful disclosure of credit terms so that the consumer will be able to compare more readily the various credit terms available to him and avoid the uninformed use of credit. ..." Presumably, informed consumers could then make choices that are most appropriate to their individual circumstances.

Even though measurement of the precise effect of particular disclosure requirements on credit-use behavior or competition is problematic, one can study consumers' reports of their views about marketplace information conditions and their uses of required disclosures. To this end, the Federal Reserve Board and others have periodically sponsored and analyzed consumer surveys on disclosure matters since 1969, when the original act was implemented. ${ }^{\text {I Over }}$ the years, survey questions have covered consumers' experiences with a variety of credit and related products, including mortgages, home equity loans, installment credit, credit cards, and credit insurance. In this article, the results of two surveys undertaken in 2001 of consumers' opinions about information availabil-

1. See Board of Governors of the Federal Reserve System, Annual Report on Truth in Lending for the Year 1970 (Washington: Board of Governors of the Federal Reserve System, 1971); National Commission on Consumer Finance, Consumer Credit in the United States: The Report of the National Commission on Constumer Finance (Washington: Government Printing Office, 1972); Thomas A. Durkin and Gregory Elliehausen, The 1977 Consumer Credit Survey (Washington: Board of Governors of the Federal Reserve System, 1978); Glenn B. Canner, Thomas A. Durkin, and Charles A. Luckett, "Home Equity Lending: Evidence from Recent Surveys," Federal Reserve Bulletin. vol. 80 (July 1994), pp. 571-83; Glenn B. Canner, Thomas A. Durkin, and Charles A. Luckett, "Recent Developments in Home Equity Lending," Federal Reserve Bulletin, vol. 84 (April 1998), pp. 241-56; and Thomas A. Durkin, "Credit Cards: Use and Consumer Attitudes," Federal Reserve Bulletin, vol. 86 (September 2000), pp. 623-34. 
ity are examined in the context of the earlier survey findings. The new data focus on consumers who use two, sometimes controversial, financial productscredit cards and credit insurance. When relevant, consumers' attitudes toward and experiences with these products are compared with earlier survey findings regarding these and other credit products. ${ }^{2}$

\section{SURVEYS OF CRFDIT CARD USERS}

Consumer surveys have shown that from 1970 to date, growth in the number of credit card accounts and their use has been substantial. ${ }^{3}$ By 1995 about three-fourths of American families held at least one credit card and about two-thirds of families held a general-purpose card with a revolving feature ("bank-type" cards like Discover, MasterCard, or Visa). Much of the growth of consumer credit in recent years has been in the form of revolving credit, of which credit card credit is the largest component. ${ }^{4}$ Card holding has grown within all income segments of the population, and by 1995 , about 95 percent of

2. The surveys in 2000 and 2001 that are cited in this article were undertaken by the Survey Research Center of the University of Michigan for the Credit Research Center of the McDonough School of Business, Georgetown University, and used questionnaires designed by the author. In the January 2001 survey on credit cards, 506 interviews were conducted; in the September-October 2001 survey on credit insurance, 1,006 interviews were conducted. The other surveys cited in this article were undertaken by the University of Michigan Survey Research Center for the Federal Reserve Board, except the 1995 and 1998 Surveys of Consumer Finances that were undertaken by the National Opinion Research Center of the University of Chicago for the Federal Reserve Board and the 1969 and 1970 Truth in Lending Surveys undertaken for the Federal Reserve Board by Chilton Research Corp. 26.

3. Durkin, "Credit Cards: Use and Consumer Attitudes," pp. 623

4. Consumer credit covers most short- and intermediate-term credit extended to individuals. It includes revolving credit (credit card credit and balances outstanding on unsecured lines of credit) and nonrevolv. ing credit (such as secured and unsecured credit for automobiles, móbile homes, trailers, durable goods, vacations, and other purposes). Consumer credit excludes loans secured by real estate (such as mortgage loans, home equity loans, and home equity lines of credit). Revolving consumer credit is often referred to as "open-end" consumer credit, and nonrevolving consumer credit is often referred to as "closed-end" consumer credit.

Open-end and closed-end credit are the terms used in Regulation Z (Truth in Lending) to describe revolving and nonrevolving consumer credit. The regulation carefully defines open-end credit as "consumer credit extended under a plan in which (i) the creditor reasonably contemplates repeated transactions; (ii) the creditor may impose a finance charge from time to time on an outstanding unpaid balance; and (iii) the amount of credit that may be extended to the consumer during the term of the plan (up to any limit set by the creditor) is generally made available to the extent that the outstanding balance is repaid" (Regulation Z 226.2(a)(10)). Closed-end consumer credit is then defined as "other than open-end credit" (Regulation $Z$ $226.2(\mathrm{a})(20))$
1. Frequencies of behaviors concerning credit card use, within groups of respondents, 2001

Percent

\begin{tabular}{|c|c|}
\hline Group and behavior & Percent \\
\hline $\begin{array}{l}\text { All families } \\
\text { Have general-purpose credit card with a revolving } \\
\quad \text { feature ("bank-type" credit cards) }\end{array}$ & 72 \\
\hline $\begin{array}{l}\text { Holders of a general-purpose card with a revolving feature } \\
\text { Acquired a new bank-type card account in past year }\end{array}$ & 20 \\
\hline 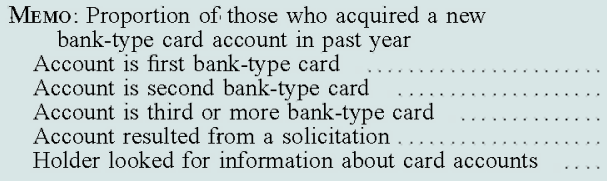 & $\begin{array}{l}15 \\
22 \\
63 \\
84 \\
25\end{array}$ \\
\hline Have three or more bank-type credit card accounts & 41 \\
\hline $\begin{array}{l}\text { Have outstanding balance greater than } \$ 1,500 \text { on bank-type } \\
\text { credit card accounts after most recent payment }\end{array}$ & 35 \\
\hline $\begin{array}{l}\text { Have transferred a balance to another bank-type } \\
\text { credit card account in the past year }\end{array}$ & 20 \\
\hline Hardly ever pay outstanding balance in full . & 29 \\
\hline Have paid a late fee in the past year & 30 \\
\hline
\end{tabular}

SOURCE. Surveys of Consumers.

households in the highest income quintile held banktype cards. ${ }^{5}$

The January 2001 survey on credit cards shows that the proportion of families that hold bank-type credit cards appears to have continued to grow since 1995 and has risen to about 72 percent of families in the contiguous forty-eight states (table 1 ). ${ }^{6}$ There is also turnover in the cards held as current holders acquire both replacement accounts and additional card accounts. About 20 percent of consumers with bank-type cards in January 2001 reported that they had obtained one or more new accounts during the previous year. A small proportion of the new accounts were the first such accounts for those who previously did not have any bank-type cards, but most were additional or replacement accounts for those already possessing similar cards. The survey found that among those with any bank-type cards, about 41 percent held three or more such accounts.

\section{Desired Information}

The ready availability of new card accounts often raises questions about the usefulness of the information on credit terms provided through required disclo-

5. Durkin, "Credit Cards: Use and Consumer Attitudes," table 2, p. 626 .

6. There is a confidence interval around all statistics from surveys. For example, with 95 percent confidence the population value would be within \pm 4.6 percentage points of this proportion. 
2. Desired information on new credit card accounts, within groups of respondents, 2001 Percent

\begin{tabular}{|c|c|c|c|c|}
\hline \multirow{2}{*}{ Desired information } & \multicolumn{2}{|c|}{$\begin{array}{l}\text { Those with no } \\
\text { bank-typ : cards }\end{array}$} & \multicolumn{2}{|c|}{$\begin{array}{c}\text { Those with } \\
\text { bank-ty } x \text { virdid }\end{array}$} \\
\hline & Important' & $\begin{array}{c}\text { Most } \\
\text { important }\end{array}$ & Important ${ }^{1}$ & $\begin{array}{c}\text { Most } \\
\text { important }\end{array}$ \\
\hline Rates/finance charges & 66 & 60 & 67 & 54 \\
\hline Annual/membership fee & 13 & 1 & 27 & 10 \\
\hline Late/penalty fee ... & 8 & 2 & 9 & 2 \\
\hline Grace period $\ldots$ & 7 & 4 & 8 & 3 \\
\hline Fixed/variable rate & 4 & 1 & 7 & 5 \\
\hline Minimum payment $\ldots$ & 2 & $*$ & 9 & 3 \\
\hline None $\ldots$ & 5 & 5 & 3 & 3 \\
\hline Other responses ' ........ & 18 & 10 & 22 & 10 \\
\hline Do not know ........ & 17 & 17 & 10 & 10 \\
\hline Total ......... & $\ldots$ & 100 & $\cdots$ & 100 \\
\hline $\begin{array}{l}\text { MEmo: Do not want } \\
\text { another card } \\
\text { (excluded from } \\
\text { other percentage } \\
\text { calculations) ...... }\end{array}$ & 9 & . & * & $\ldots$ \\
\hline $\begin{array}{l}\text { 1. Adds to more than } 100 \\
\text { answers. } \\
\text { 2. Examples include infor } \\
\text { oroduct insurance, and on fre } \\
\text { " Less than } 1.5 \text { percent. } \\
\text {. . Vol ipplicalylit. } \\
\text { Source. Surveys of Cons }\end{array}$ & $\begin{array}{l}\text { percent becal } \\
\text { mation on the } \\
\text { quent flyer } b\end{array}$ & $\begin{array}{l}\text { use respond } \\
\text { eredit limi } \\
\text { enefits. }\end{array}$ & $\begin{array}{l}\text { ents could giv } \\
\text { on credit in }\end{array}$ & re up to two \\
\hline
\end{tabular}

sures (some of which creditors might have disclosed anyway). To ascertain opinions about information considered useful, the 2001 survey first asked consumers about information they would like to have if they were opening a new credit card account. Specifically, consumers both with and without bank-type card accounts were asked what they would like to know about the credit terms if they were shopping for a general-purpose credit card like Visa or MasterCard. The question was asked in an open-end form so as not to produce any preconceived response, and respondents were permitted to give up to two responses. Consumers giving more than one answer were also asked which item they considered most important.

Although respondents offered a variety of answers concerning important credit terms, cost items predominated - notably percentage rates and finance charges, which are the main focus of the required disclosures. About two-thirds of those who did not have a bank-type credit card indicated that interest rates or finance charges were important terms, and three-fifths said that these were the most important terms they would want to know (table 2).

Among those currently holding such cards, the proportion indicating that interest rates and finance charges were important was also about two-thirds. Only slightly more than half ( 54 percent), however, cited these measures as the most important terms to consider if they were seeking a new card account. In opening a new or replacement account, those who already have one or more general-purpose credit cards assign a higher level of importance to annual fees, fixed versus variable rates, and even frequent flier miles than those who do not have such cards. Finally, 10 percent of consumers with bank-type cards said that they did not know which term was most important, likely because, for some of them, two or more terms were equally important. Among those without any bank-type card accounts, the proportion indicating that they did not know which term was most important to them reached 17 percent.

To ascertain a relative ranking of the importance of various credit terms, including primary cost terms, all respondents with bank-type credit cards were asked a further series of questions about the terms they considered most important. The questions did not require consumers specifically to rank terms in order of importance, largely because of the difficulty in a telephone interview for respondents to recall the

3. Importance of credit terms among holders of bank-type credit cards, 2001

Percent

\begin{tabular}{|c|c|c|c|c|c|}
\hline Credit term & Very important & Somewhat important & Not too important & Not at all important & Do not know \\
\hline Amount of the annual fee $\ldots \ldots \ldots \ldots$ & 76 & 19 & 3 & 2 & $*$ \\
\hline Annual percentage rate of interest & 78 & 13 & 5 & 5 & $*$ \\
\hline Length of grace period & 42 & 41 & 11 & 6 & 1 \\
\hline Amount of the credit limit & 36 & 41 & 13 & 9 & $\approx$ \\
\hline $\begin{array}{l}\text { Length of time to pay off accoun. } \\
\text { if making minimum payment }\end{array}$ & 52 & 18 & 15 & 14 & 1 \\
\hline Amount of minimum payment & 30 & 37 & 19 & 14 & $*$ \\
\hline $\begin{array}{l}\text { Rewards like cash back, merchandise } \\
\text { or frequent flyer miles }\end{array}$ & 25 & 31 & 20 & 24 & 1 \\
\hline
\end{tabular}


complete list to be ranked. Instead, the survey asked respondents how important various terms were to them, and their responses about importance provided the underpinnings for a constructed ranking.

Ordering credit terms according to the proportion of respondents who reported that a certain term was either "very important" or "somewhat important" shows that annual fees and annual percentage rates took the top two spots (table 3). These cost terms were followed in order by other credit terms such as length of grace period, amount of the credit line, length of time to repay if making the minimum payment, and amount of the minimum payment itself. (The order changes slightly if ranked only according to terms judged "very important.") Rewards like frequent flier miles fell into last place among the terms explored.

\section{New Accounts}

The survey also asked those opening new card accounts in the year before January 2001 whether the new account was established through a solicitation from a card issuer or through action initiated by the consumer. Interview results indicate that most of the new accounts opened during that year-more than four-fifths of the relatively small sample of new account holders-were established through a solicitation (table 1).

The consumers with new accounts were also asked whether they had attempted to obtain any information about other credit card companies or card accounts before opening the new account-in effect whether they had engaged in any credit-shopping activities. In response, 25 percent of the small sample of new account holders replied that they had sought some additional information (table 4). The number of holders of new bank-type credit card accounts who also sought additional information is necessarily small (in this case, only eighteen respondents on an unweighted basis) in a survey of limited sample size, and so findings are not precisely estimated and are, at best, only indicative. Nonetheless, the proportion of this small group who sought information and focused on percentage rates or fees and charges is very similar to survey findings from larger surveys in past years concerning the kinds of information looked for in closed-end credit disclosures. Likewise, the high proportion of information seekers saying that they were able to find the information sought, 91 percent, also closely matches the results of the earlier, larger surveys of users of closed-end credit.

\section{Perceptions of Information Availability}

Following the credit-shopping question, a series of questions queried all respondents with bank-type card accounts about their perceptions of information availability for such accounts. The first question asked about the degree of difficulty in obtaining useful information about credit terms. This question and some further questions made a distinction between respondents' views of their own experiences with information and their conception of the experiences of others. The questioning specified this differentiation because a previous survey of credit card holders indicated that reports about consumers' own experiences might well differ from their views of the experiences of unknown others, a finding dubbed the "other-guy effect." "7

Almost two-thirds ( 65 percent) of holders of banktype card accounts in the 2001 survey reported believing that useful information on credit terms was

7. See Durkin, "Credit Cards: Use and Consumer Attitudes," p. 628 .

4. Consumers who engaged in search for credit information, selected years, 1977-2001

Percent

\begin{tabular}{|c|c|c|c|c|c|}
\hline Item & 1977 & 1981 & 1994 & 1997 & 2001 \\
\hline Tried to obtain information ${ }^{1}$ & \multirow[t]{2}{*}{26} & \multirow[t]{2}{*}{26} & \multirow[t]{2}{*}{37} & \multirow[t]{2}{*}{33} & \multirow[t]{2}{*}{25} \\
\hline $\begin{array}{l}\text { Kind of information sought (percentage } \\
\text { of those who sought information) }\end{array}$ & & & & & \\
\hline Interest rates $\ldots \ldots \ldots \ldots \ldots \ldots \ldots$ & 73 & 83 & 81 & 88 & 85 \\
\hline Fees and charges & 12 & 30 & 16 & 14 & 25 \\
\hline $\begin{array}{l}\text { Able to obtain information sought (percentage of those } \\
\text { who sought information) }\end{array}$ & 91 & 96 & 95 & 88 & 91 \\
\hline
\end{tabular}

1 For 1977, percentage of families with closed-end installment debt outstanding; for 1981, 1994, and 1997, percentage of families that had incurred closed-end installment debt in the past year; for 2001, percentage of holders of bank-type credit cards who had acquired a new card in the previous year. 
5. Opinions of consumer credit users concerning ease of obtaining information on credit terms and on adequacy of information provided, selected years, 1977-2001

Percent ${ }^{1}$

\begin{tabular}{|c|c|c|c|c|c|c|}
\hline \multirow[b]{2}{*}{ Opinion } & \multirow[b]{2}{*}{1977} & \multirow[b]{2}{*}{1981} & \multirow[b]{2}{*}{1994} & \multirow[b]{2}{*}{1997} & \multicolumn{2}{|c|}{2001} \\
\hline & & & & & $\begin{array}{l}\text { For } \\
\text { self }\end{array}$ & $\begin{array}{c}\text { For } \\
\text { others }\end{array}$ \\
\hline 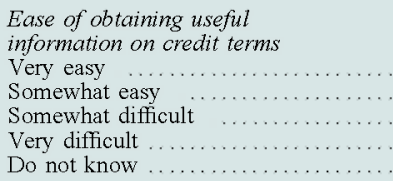 & $\begin{array}{r}23 \\
39 \\
29 \\
8 \\
1\end{array}$ & $\begin{array}{c}28 \\
48 \\
21 \\
4 \\
*\end{array}$ & $\begin{array}{r}23 \\
48 \\
23 \\
5 \\
1\end{array}$ & $\begin{array}{r}23 \\
49 \\
25 \\
3 \\
*\end{array}$ & $\begin{array}{r}21 \\
44 \\
26 \\
6 \\
3\end{array}$ & $\begin{array}{r}11 \\
32 \\
36 \\
11 \\
9\end{array}$ \\
\hline Total & 100 & 100 & 100 & 100 & 100 & 100 \\
\hline $\begin{array}{l}\text { Creditors provide enough information } \\
\text { Yes } \\
\text { Some do/Some do not } \\
\text { No } \ldots \ldots \\
\text { Do not know }\end{array}$ & $\begin{array}{r}44 \\
13 \\
38 \\
4\end{array}$ & $\begin{array}{r}65 \\
7 \\
27 \\
1\end{array}$ & $\begin{array}{r}62 \\
5 \\
30 \\
2\end{array}$ & $\begin{array}{r}61 \\
9 \\
29 \\
1\end{array}$ & $\begin{array}{r}65 \\
2 \\
31 \\
1\end{array}$ & $\begin{array}{r}49 \\
4 \\
43 \\
4\end{array}$ \\
\hline Total & 100 & 100 & 100 & 100 & 100 & 100 \\
\hline
\end{tabular}

NoTE. Components may not sum to 100 because of rounding.

1 For 1977, percentage of families with closed-end installment debt outstanding; for 1981, 1994, and 1997, percentage of families that had incurred closed-end installment debt in the past year; for 2001, percentage of holders of bank-type credit cards.

either "very easy" or "somewhat easy" to obtain for themselves (first panel of table 5). In contrast, only 6 percent believed that obtaining this information was "very difficult." This finding is comparable to the results of the same question asked about perceived difficulties in obtaining information on closedend credit accounts in earlier surveys, but it differs substantially from current respondents' views of the experiences of others with credit card accounts. Fewer than half of holders of bank-type cards believed that it was easy for others to acquire useful information on credit terms.

A related follow-up question produced a similar outcome. When queried about whether credit card companies usually provide enough information to enable them to use credit cards wisely, about twothirds of respondents answered affirmatively; when the same question was asked about their perception of the experience of others, slightly less than half answered affirmatively (second panel of table 5). The question was asked in this manner not with the expectation of learning something about respondents' view of what was "wise," but rather with the goal of comparing the results with those for the same question asked in the past of users of closed-end installment credit. Again, current responses are quite similar to previous experience with questioning about closed-end credit, at least after 1977 when responses were different, possibly reflecting the relative newness of Truth in Lending disclosures at that time and consumers' lack of experience with them.
" Less than (1.5 percent.

SourCE. 1977 Consumer Credit Survey; Surveys of Consumers.

Another question explored further the distinction between views about personal experience with credit cards and that of others. This question asked whether "your general purpose credit card(s) with a revolving feature that give(s) you the option of paying part of the balance made managing your finances easier or more difficult?" Almost 90 percent of respondents replied that such cards made managing finances either easier or that there was no difference; only about 10 percent indicated that managing finances was more difficult (table 6).

When asked further why credit cards have made managing finances easier, the majority of respondents stressed aspects of flexibility, especially the smoothing of expenditure and repayment that credit cards permit. The smaller proportion who did not find that credit cards made managing finances easier most

6. Opinions of credit users concerning the effects of credit cards on personal financial management, 2001

Percent

\begin{tabular}{|c|c|c|}
\hline \multirow{2}{*}{ Opinion } & \multicolumn{2}{|c|}{2001} \\
\hline & For self & For others \\
\hline $\begin{array}{l}\text { Credit cards make } \\
\text { managing finances }\end{array}$ & & \\
\hline Easier...$\ldots \ldots \ldots$ & 73 & 53 \\
\hline No different & 16 & 2 \\
\hline More difficult & 10 & 40 \\
\hline Do not know & 2 & 5 \\
\hline Total & 100 & 100 \\
\hline
\end{tabular}

NoTE. Components may not sum to 100 because of rounding. SourCE. Surveys of Consumers. 
7. Overall satisfaction of consumers with credit, by type of credit, selected years, 1981-2001

Percent ${ }^{1}$

\begin{tabular}{|c|c|c|c|c|c|c|}
\hline \multirow{2}{*}{ Opinion } & \multirow{2}{*}{$\begin{array}{l}1977 \\
\text { Closed-end } \\
\text { installment }\end{array}$} & \multicolumn{2}{|c|}{1994} & \multicolumn{2}{|c|}{1997} & \multirow{2}{*}{$\begin{array}{l}2001 \\
\text { Bank-type } \\
\text { credit card }\end{array}$} \\
\hline & & HELC & Installment & HELC & Installment & \\
\hline \multicolumn{7}{|l|}{ Overall satisfaction with credit } \\
\hline Very satisfied & 77 & 69 & 56 & 75 & 63 & 48 \\
\hline Somewhat satisfied & 18 & 27 & 32 & 21 & 29 & 42 \\
\hline Not particularly satisfied or dissatisfied & 3 & 2 & 5 & $\dot{s}$ & 4 & 5 \\
\hline Somewhat dissatisfied & 2 & 2 & 2 & $\approx$ & 1 & 5 \\
\hline Very dissatisfied & 1 & 1 & 5 & 2 & 3 & 1 \\
\hline Do not know & $\approx$ & $\approx$ & $\approx$ & 1 & $*$ & $*$ \\
\hline Total & 100 & 100 & 100 & 100 & 100 & 100 \\
\hline \multicolumn{3}{|c|}{$\begin{array}{l}\text { Note. Components may not sum to } 100 \text { because of rounding. } \\
\text { 1 For } 1977 \text {, percentage of families with closed-end installment debt out- } \\
\text { tanding; in } 1994 \text { and } 1997 \text {, percentage of families with open home equity lines } \\
\text { f credit (HELC, with or without an outstanding balance, first column for each }\end{array}$} & \multicolumn{4}{|c|}{$\begin{array}{l}\text { (second column for each year); in 2001, percentage of holders of bank-typ } \\
\text { credit cards. } \\
\quad \text { \&.Lss thin i..5 percent. } \\
\text { SourCE. } 1977 \text { Consumer Credit Survey; Surveys of Consumers. }\end{array}$} \\
\hline
\end{tabular}

often noted the possibility of overspending and overextending financial resources through credit card use.

The generally favorable view concerning the effect of credit cards on their personal financial management contrasts sharply with consumers' perceptions of the experiences of other people. Just over half (55 percent) of respondents indicated that, in their view, credit cards made finances of the "other guy" easier or no different. In contrast, 40 percent said that the finances of others were made more difficult by credit cards - four times the proportion with a negative view of the effect of credit cards on their own finances. The most common reasons for this contention were concerns about overspending, too much debt, and a continuing cycle of debt among the unknown other consumers.

The generally favorable view of respondents about information availability and their own circumstances is heartening in that it seems to suggest directly and indirectly that many people are relatively satisfied with their ability to obtain and use the information currently disclosed. This generally favorable attitude contrasts with respondents' perspectives on the experiences of others, whom they appear to regard as more vulnerable. Unknown others are considered less able to obtain and use information or to manage their finances well when using credit cards.

The generally favorable attitude toward personal experience with credit cards is supported by results of a later segment of the interview concerning overall satisfaction with credit cards. The final question asked, "Overall, how satisfied are you [emphasis stressed by interviewer] with your general-purpose credit card(s)?" The question requested a response on a five-point scale ranging from "very satisfied" to "very dissatisfied." About nine in ten indicated they were "very" or "somewhat" satisfied and only about one in twenty reported dissatisfaction (table 7). Only about 1 percent of respondents indicated that they were very dissatisfied. The pattern of responses to this question is much like earlier findings concerning installment credit and home equity credit lines, especially if the very satisfied and those who are somewhat satisfied are lumped together. The number who are dissatisfied remains quite small across the years and across credit types.

\section{Truth in Lending and Information}

An intriguing question about Truth in Lending is whether it has had a long-term effect on consumer awareness, understanding, and behavior. A question in the survey of credit card users in 2000 indicated that consumer awareness of annual percentage rates associated with credit card accounts, using the procedure for measuring awareness established by the National Commission on Consumer Finance in 1972, had increased dramatically in the three decades since implementation of the law. ${ }^{8}$ Awareness, according to the National Commission's approach, had increased from 27 percent of credit card holders before Truth in Lending, to 63 percent in 1970 (fifteen months after implementation), to 71 percent in 1977 , and in

8. Because in an interview study the researcher typically does not have access to the actual contract for verification of stated annual percentage rates (APRs), researchers associated with the National Commission on Consumer Finance devised the concept of "awareness zones" to measure knowledge of APRs in interviews. If a respondent reported an APR within a range deemed to be reasonable on the basis of a survey of current market practices, then the respondent was characterized as "aware." If the respondent gave a response outside the range or answered "do not know," then the individual was listed as "unaware." Although this procedure obviously is somewhat inexact for measuring actual awareness of APR charges on actual credit transactions, it does permit a broad look at the phenomenon, and it allows comparisons over time. For further discussion of the awareness zones used by the National Commission and to make comparisons with survey findings in 2000, see Durkin, "Credit Cards: Use and Consumer Attitudes," pp. 630-31. 
8. Opinions of credit users concerning helpfulness of Truth in Lending statements, by type of credit, selected years, 1981-2001

Percent ${ }^{1}$

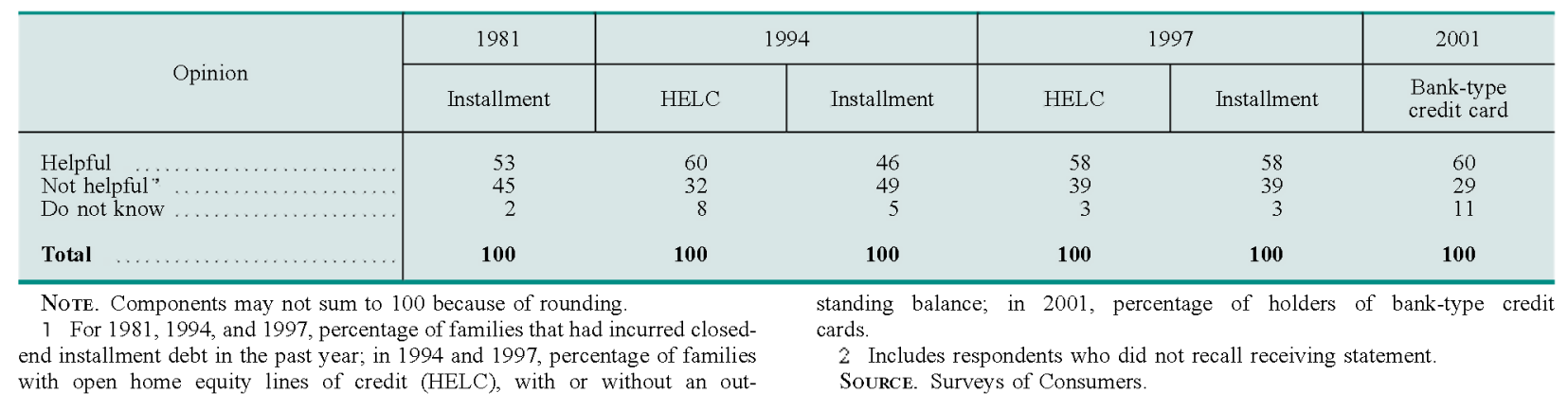

2000 to 85 percent and 91 percent, respectively, for the "narrow" and "broad" definitions of awareness employed in the 2000 survey. The 2001 survey confirmed the long-term rise in the awareness level to year 2000, with awareness recorded in 2001 under the same definitions at 82 percent and 88 percent (not shown in table), a result within the normal range for statistical variation. The 2001 survey also asked several additional questions related to Truth in Lending, specifically about consumers' understanding and use of Truth in Lending information on bank-type credit cards. Again, the questions were the same ones employed in the past to study information use for closed-end credit.

The first question stated that the "federal Truth in Lending Law requires that credit card companies provide consumers with written statements of credit costs when a new account is opened and as part of the monthly bill." Then the interviewer asked "Is the Truth in Lending statement helpful in any way?" Sixty percent of consumers with bank-type credit cards indicated in 2001 that the Truth in Lending statement was helpful, whereas 29 percent responded that it was not (table 8). These results are broadly similar to past findings, although the proportion that found it helpful is a bit higher, and the proportion that did not find it helpful a bit lower, than responses about Truth in Lending statements on various forms of closed-end credit in most past measurements. About 11 percent of respondents maintained that they did not know whether the statement was helpful or not, a percentage that was a bit higher than on earlier surveys.

When quizzed further, "In what way is it helpful?" almost half of those indicating in 2001 that the statement was helpful responded with a generic response that it provided general information on terms and conditions (figures not in table). Thirteen percent specifically mentioned that it provided information on interest rates or finance charges, and about 10 per- cent said that it provided a good reference document if problems arose.

Another follow-up question in 2001 asked both those who felt the statement was useful and those who did not how the Truth in Lending statement could be made more helpful. Slightly more than two-fifths of those indicating that it was already helpful said that they did not know how it could be made more helpful (not in table). Another 15 percent said that it could not be made more helpful, but about 28 percent of these favorable responses mentioned issues of format and clarity: It could be clearer, simpler, easier to understand, written in lay terms, or have larger print.

Among the three-tenths of respondents who indicated that the Truth in Lending statement was not helpful, again about two-fifths said that they did not know how it could be more helpful, but almost half of the group contending that the statement was not helpful mentioned various format and clarity issues. A number of consumers responded with a variety of other things they considered potentially useful. These answers ranged from sending a representative to consumers' homes to explain account terms to enforcing the laws and making the Truth in Lending Act mandatory reading for all consumers entering into credit contracts.

The survey next asked respondents directly about whether the Truth in Lending statement had affected their decision to use credit cards in any way. About 18 percent of respondents indicated that the statement had affected their decisions, whereas 77 percent said it had not (not in table). About 5 percent said they did not know. Among the minority of consumers who reported that the Truth in Lending statement had affected their credit decision, about half said that it helped in deciding whether to obtain a card and in choosing which card. A bit more than one-fourth of this group said that it made them more cautious in using credit. 
9. Consumers' agreement with observations about Truth in Lending statements, selected years, 1977-2001

Percent ${ }^{1}$

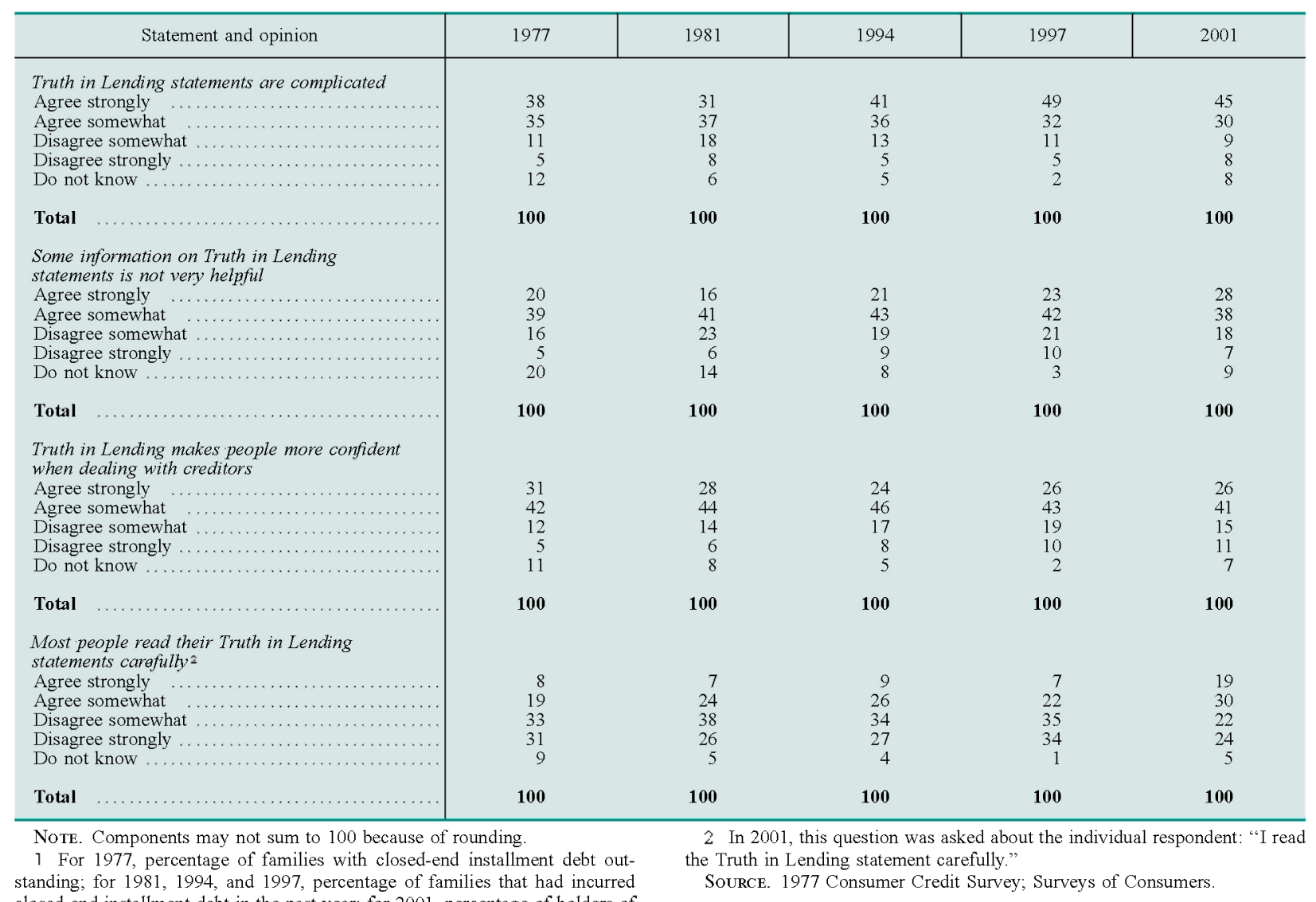

closed-end installment debt in the past vear; for 2001 , percentage of holders of

bank-type credit cards.

Over the years, consumer surveys have also asked about general perceptions of Truth in Lending statements. It is clear from the responses to this line of questioning that typical credit users consider Truth in Lending statements to be complicated: Consistently about two-thirds to three-fourths of consumers somewhat or strongly agree with the statement that Truth in Lending statements are complicated (table 9). Likewise, about three-fifths to two-thirds of consumers somewhat or strongly agree that some information on the statements is not very helpful.

On the positive side, approximately seven-tenths of respondents affirm the view that Truth in Lending makes people more confident when dealing with creditors, a result that may be an additional benefit of the law. Consumers may feel that the statements are complicated and that not every element is always useful, but they appear to like knowing that the behavior of creditors is being monitored. The only striking difference in the responses of consumers over time to this sequence of questions again appears related to the "other-guy" effect: Only about three- tenths of respondents to earlier surveys have agreed with the view that most consumers read their Truth in Lending statements carefully. After a change in wording in 2001 to focus this question on the individual, rather than on consumers in general, about half of the respondents reported that they read the statements carefully themselves. This result likely reflects a degree of "yea saying" by respondents to give the interviewer what might be perceived as an answer that is in some sense correct. It probably also mirrors, however, a degree of belief among consumers that they exercise reasonable care themselves but that others may be less inclined to do so.

\section{SURVEYS OF CREDIT INSURANCE USERS}

Credit life insurance repays a debt upon the death of the insured debtor, while credit disability insurance (sometimes called credit accident and health insurance) and credit involuntary unemployment insurance make the periodic payments on a debt if any 
of the insured events occur. The products have long been controversial because some observers see such insurance as involving a high and unnecessary cost for sometimes beleaguered credit users. They believe that creditors are often too aggressive in selling credit insurance, both because it earns sales commissions from the insurance companies, which may be affiliates, and because it mostly protects the creditors by guaranteeing repayment of debts upon death, disability, or involuntary unemployment of a debtor. A frequent complaint is that the price is too high, making the loss ratio-which is the proportion of total premiums returned to consumers who suffer an insured loss- too low. In this view, the insurance company simply keeps too much of the premium dollars.

Others see the product as safeguarding not creditors, but rather underinsured individuals and their families who could otherwise face financial uncertainty and distress from an unpaid debt in the event of an uninsured personal disaster. In this view, consumers buy the insurance because they want it, not because it is sold overly aggressively. Furthermore, in this view, loss ratios are reasonable because states set the rates at a level that provides sufficient benefits to the insured without jeopardizing the financial viability of the insurance companies."

Because of the controversial nature of this product, the original Truth in Lending Act in 1968 contained a special disclosure for credit insurance that remains unchanged today. In order for the credit insurance premium to be excluded from the finance charge and the annual percentage rate, the creditor must provide a written disclosure of the cost and notification that the purchase is voluntary (not a factor in the decision to extend credit). After receiving these disclosures, the consumer must specifically affirm the purchase in writing.

This approach makes Truth in Lending treatment of the purchase of credit insurance unlike any other component of a credit transaction, but it has not eliminated concerns about sales of this product. Detractors argue that creditors are still overly aggres-

9. Ultimately, the dispute over the appropriate loss ratio on credit insurance is a pricing issue that is beyond the scope of this article, which deals only with surveys concerning consumer acceptance of credit insurance and attitudes toward it. The maximum permitted rate in a state, called the prima facie rate, is governed by state law or regulation with the intent of producing a loss ratio that provides sufficient benefits to consumers while protecting the solvency of insurance companies operating in the state. Those who favor a higher loss ratio for credit insurance believe either that the benefits to consumers are insufficient under the state's regulation or that the loss ratio in the state does not meet the state's own requirement; consequently, they want states to require credit insurance companies to lower prices sufficiently to raise the loss ratio to a preferred level. sive in selling credit insurance, despite the separately signed disclosure that purchase is voluntary. In large part because of this contention, surveys sponsored by the Federal Reserve and others over the years have examined consumers' views about various aspects of the purchase of credit insurance, including their acceptance of the product and their views of the sales process. ${ }^{10}$

\section{Sales-Penetration Rat?}

The survey in September-October 2001 of consumer attitudes toward credit insurance shows that the frequency of purchase of credit insurance on closedend consumer installment credit, generally referred to as the sales-penetration rate, has declined sharply in recent years. (Closed-end installment credit is the only kind of credit for which comparison of consumer-survey findings over time is possible because past surveys of credit insurance users did not look at insurance on other types of credit.) From sales penetration exceeding three-fifths of borrowers in 1977 and 1985, the ratio fell to only slightly more than one-fifth in 2001 (table 10). This decline mirrors the falloff in the proportion of life insurance in force represented by credit-related insurance over approximately the same time period." In 2001 the penetration rate on junior-lien mortgage and credit card credit is similar to the rate on installment credit, with the rate on first-lien mortgage credit a bit higher. ${ }^{12}$

10. Earlier survey results are found in the following sources: Charles L. Hubbard, ed., Constumer Credit Life and Disability Insturance (Athens, Ohio: College of Business Administration, Ohio University, 1973); Thomas A. Durkin and Gregory E. Elliehausen, The 1977 Consumer Credit Survey (Washington: Board of Governors of the Federal Reserve System, 1978); Robert A. Eisenbeis and Paul R. Schweitzer, Tie Ins Between the Granting of Credit and Sales of Insurance By Bank Holding Companies and Other Lenders, Staff Studies 101 (Board of Governors of the Federal Reserve System, 1979); Anthony W. Cyrnak and Glenn B. Canner, "Consumer Experiences with Credit Insurance: Some New Evidence," Federal Reserve Bank of San Francisco, Economic Review (Summer 1986), pp. 5-20; and John M. Barron and Michael E. Staten, Consumer Attitudes Toward Credit Insurance (Norwell, Massachusetts: Kluwer Academic Publishers, 1996).

11. According to the Life Insurers Fact Book 2000 (Washington: American Council of Life Insurers, 2000), at year-end 1999 there was $\$ 213$ billion of credit life insurance in force, about 1 percent of the total of life insurance in force in the United States. The volume of credit life insurance in force peaked in 1989 at $\$ 260$ billion, which represented about 3 percent of life insurance in force at that time.

12. Some of the credit insurance reported on first-lien mortgage credit may possibly be other kinds of term life insurance purchased at or near the time of mortgage origination that meets the description of credit-related insurance in the minds of consumer respondents. This possibility would be less likely with junior-lien credit and especially with insurance on installment credit because the typical amounts of credit are smaller and less likely to generate a search for an alternative or separate life insurance plan. 
10. Distribution of sales penetration rates for credit insurance, by type of credit, selected years, 1977-2001

Percent

\begin{tabular}{|c|c|c|c|c|c|c|}
\hline \multirow{2}{*}{ Ownership } & 1977 & 1985 & 2001 & \multicolumn{3}{|c|}{2001} \\
\hline & \multicolumn{3}{|c|}{ Installment credit } & $\begin{array}{c}\text { First } \\
\text { mortgage }\end{array}$ & $\begin{array}{c}\text { Second } \\
\text { mortgage/HELC }\end{array}$ & $\begin{array}{l}\text { Credit } \\
\text { card }\end{array}$ \\
\hline Have & 63.9 & 64.7 & 22.7 & 32.1 & 22.9 & 20.1 \\
\hline Do not have & 30.1 & 33.1 & 74.4 & 60.5 & 65.1 & 73.9 \\
\hline Do not know/Decline to answer & 6.0 & 2.2 & 2.9 & 7.4 & 12.0 & 6.0 \\
\hline Total & 100.0 & 100.0 & 100.0 & 100.0 & 100.0 & 100.0 \\
\hline
\end{tabular}

Source. 1977 Consumer Credit Survey; Surveys of Consumers

Some consumers do not purchase credit insurance apparently because creditors do not always offer it, or at least not vigorously enough for consumers to be aware of any sales effort. In the 1977, 1985, and 2001 surveys, about half of nonpurchasers of credit insurance on installment credit indicated that the product was never offered to them (first panel of table 11). Only a small (and declining) proportion of nonpurchasers said that the creditor recommended the product.

Not surprisingly, a higher proportion of those purchasing insurance said that the creditor had offered or recommended the product, but the proportion of con- sumers who have felt pressured to purchase appears to have declined over the years. In 1977 about twofifths of purchasers indicated that the creditor had strongly recommended or even required purchase. By 2001 this proportion had declined to less than onefifth, and only about one purchaser in twenty among a smaller number of purchasers felt that they were led to believe that purchase was required.

A relatively small but rising proportion of consumers who said the creditor never mentioned the product also said they had purchased it. This finding probably represents the rising prevalence of post-purchase telemarketing and mail solicitation in recent years.

11. Distribution of recommendation to purchase credit insurance and opinions of credit insurance by users of installment credit, selected years, 1977-2001

Percent

\begin{tabular}{|c|c|c|c|c|c|c|}
\hline \multirow{2}{*}{ Item } & \multicolumn{2}{|c|}{1977} & \multicolumn{2}{|c|}{1985} & \multicolumn{2}{|c|}{2001} \\
\hline & Insurance & No insurance & Insurance & No insurance & Insurance & No insurance \\
\hline \multicolumn{7}{|l|}{ Recommendation } \\
\hline Never mentioned & 7.1 & 51.6 & 14.8 & 45.2 & 15.4 & 53.3 \\
\hline Offered $\ldots \ldots \ldots$ & 150 & 22.6 & 44.7 & 35.5 & 53.2 & 33.9 \\
\hline Recommended $\quad \ldots . .$. & 33.1 & 17.0 & 16.4 & 12.9 & 12.2 & 4.1 \\
\hline Strongly recommended & 13.2 & 2.3 & 6.3 & 2.6 & 11.5 & 3.4 \\
\hline 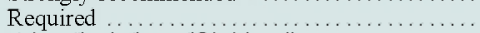 & 26.1 & $\ldots$ & 13.8 & $\cdots$ & 5.1 & $\cdots$ \\
\hline Other (includes self initiated) ... & 3.5 & .6 & $\approx$ & $\approx$ & $*$ & $*$ \\
\hline Do not know/Decline to answer. & 2.1 & 5.9 & 3.9 & 3.9 & 2.6 & 5.3 \\
\hline Total & 100.0 & 100.0 & 100.0 & 100.0 & 100.0 & 100.0 \\
\hline $\begin{array}{l}\text { MEMo: Insurance purchase irrelevant to } \\
\text { creditor's decision to grant } \text { credit }^{1} \text {. }\end{array}$ & 80.3 & 91.0 & 94.2 & 96.2 & 86.5 & 97.0 \\
\hline \multicolumn{7}{|l|}{ Opinion } \\
\hline Good ..... & 86.7 & 59.8 & 89.9 & 56.4 & 88.5 & 32.3 \\
\hline Good with qualifications $\ldots \ldots \ldots \ldots \ldots \ldots$ & 8.6 & 18.9 & 2.9 & 8.3 & 3.8 & 6.1 \\
\hline Neither good nor bad $\ldots \ldots \ldots \ldots \ldots \ldots \ldots$. & 2.1 & 9.1 & 1.9 & 6.4 & 3.2 & 13.9 \\
\hline Bad with qualifications $\ldots \ldots \ldots \ldots \ldots \ldots$ & $*$ & 2.7 & $\approx$ & 2.6 & + & 1.6 \\
\hline $\mathrm{Bad} \quad \ldots \ldots \ldots \ldots \ldots \ldots \ldots \ldots \ldots \ldots \ldots \ldots \ldots$ & 2.2 & 9.5 & 5.2 & 26.3 & 4.5 & 46.0 \\
\hline Total & 100.0 & 100.0 & 100.0 & 100.0 & 100.0 & 100.0 \\
\hline \multicolumn{7}{|l|}{ Purchase again? } \\
\hline Yes $\ldots \ldots \ldots \ldots$ & n.a. & $\cdots$ & 94.3 & $\ldots$ & 94.2 & $\cdots$ \\
\hline 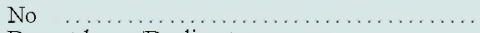 & n.a. & $\ldots$ & 5.7 & $\ldots$ & 5.8 & $\ldots$ \\
\hline Do not know/Decline to answer ............. & 11.11. & $\ldots$ & $\approx$ & $\cdots$ & $*$ & $\ldots$ \\
\hline Total & $\cdots$ & $\cdots$ & 100.0 & $\cdots$ & 100.0 & $\ldots$ \\
\hline
\end{tabular}


Another possibility is "insurance packing," that is, including insurance in the loan without notifying the consumer, but this seems unlikely in most cases. Respondents were not asked directly about insurance packing, but they were asked whether they believed that purchase of the insurance made any difference in whether the creditor was willing to grant the credit. In each year, a few respondents answered affirmatively. In each of the three surveys, a large majority of both insurance purchasers and nonpurchasers believed that purchasing credit insurance was irrelevant to this decision by installment lenders.

\section{Consumen Attitudes toward Credit Insurance}

Although sales penetration has fallen in recent decades, it seems that the favorable attitudes toward the product among those who purchase credit insurance on installment credit have not changed over time. In 2001, more than 90 percent of installment credit users with credit insurance indicated a favorable attitude toward the insurance (the product is "good" or "good" with some qualification) - almost the same proportion as in 1977 and 1985 (second panel of table 11). Furthermore, about nineteen in twenty purchasers of credit insurance on installment credit in 2001 say that they would purchase it againthe same proportion as in 1985 , the only other observation date available (third panel of table 11).

The consistently favorable attitudes among insurance purchasers contrast sharply with the views of those who do not purchase the product. Nonpurchasers reporting that the product is good or good with some qualification fell from more than three-fourths in 1977 to only about three-eighths of respondents in 2001, while unfavorable attitudes among nonpurchasers jumped sharply. The unfavorable attitude toward credit insurance among nonpurchasers likely is an important reason for their not purchasing the product.

Results of the 2001 survey also show that favorable attitudes among purchasers of credit-related insurance apparently are not limited to those who purchased it on installment credit. About threefourths of first-mortgage credit users with creditrelated insurance also held a favorable attitude toward the insurance product, a proportion reaching 90 percent among junior-lien credit users (table 12). In each case, those with the same kinds of credit outstanding but without credit insurance held much different views, likely a cause of their decision not to purchase insurance. The most unfavorable attitudes overall were held by those with no closed-end credit of any type outstanding (middle column, lower panel of table 12).

In addition to requesting an expression of attitudes, as a follow-up question the survey asked, "Why do you say that?" to ascertain the reason for the favorable or unfavorable attitude. The survey recorded up to two responses to this question. As might be expected, criteria for the viewpoint expressed differed sharply between those who had favorable and those who had unfavorable perceptions of credit

12. Distribution of consumer opinions of credit insurance, by type of credit and ownership of insurance, 2001 Percent

\begin{tabular}{|c|c|c|c|c|c|c|}
\hline \multirow{2}{*}{ Opinion } & \multicolumn{2}{|c|}{ Mor gage } & \multicolumn{2}{|c|}{ Junior mortgage/HELC } & \multicolumn{2}{|c|}{ Installment credit ${ }^{1}$} \\
\hline & Insurance & No insurance & Insurance & No insurance & Insurance & No insurance \\
\hline $\begin{array}{l}\text { Good } \\
\text { Good with qualifications } \\
\text { Neither good nor bad } \\
\text { Bad with qualifications } \\
\text { Bad } \\
\text { Do not know/Decline to answer. } \\
\text { Do }\end{array}$ & $\begin{array}{r}74.7 \\
2.1 \\
4.5 \\
.8 \\
9.9 \\
8.0\end{array}$ & $\begin{array}{r}35.6 \\
3.6 \\
10.6 \\
1.2 \\
46.0 \\
2.9\end{array}$ & $\begin{array}{l}90.7 \\
* \\
7.2 \\
\approx \\
\approx \\
2.1\end{array}$ & $\begin{array}{r}34.8 \\
8.0 \\
9.4 \\
2.9 \\
44.9 \\
\end{array}$ & $\begin{array}{r}88.5 \\
3.8 \\
3.2 \\
\$ \\
4.5 \\
8\end{array}$ & $\begin{array}{r}31.3 \\
5.9 \\
13.5 \\
1.6 \\
44.6 \\
3.1\end{array}$ \\
\hline \multirow[t]{3}{*}{ Total $\ldots \ldots \ldots \ldots \ldots \ldots \ldots$} & 100.0 & 100.0 & 100.0 & 100.0 & 100.0 & 100.0 \\
\hline & \multicolumn{2}{|c|}{ Any close - -end credit } & \multicolumn{2}{|c|}{ No closed-end credit } & \multicolumn{2}{|c|}{ Credit card } \\
\hline & Insurance & No insurance & \multicolumn{2}{|c|}{ No insurance } & Insurance & No insurance \\
\hline $\begin{array}{l}\text { Good } \\
\text { Good with qualifications } \\
\text { Neither good nor bad } \\
\text { Bad with qualifications } \\
\text { Bad } \\
\text { Do not know/Decline to answer } \\
\end{array}$ & $\begin{array}{r}77.6 \\
2.4 \\
5.0 \\
.6 \\
8.4 \\
5.9\end{array}$ & $\begin{array}{r}37.0 \\
3.7 \\
9.7 \\
1.0 \\
45.5 \\
3.0\end{array}$ & & & $\begin{array}{r}56.6 \\
1.9 \\
5.6 \\
\$ \\
30.4 \\
5.6\end{array}$ & $\begin{array}{r}35.4 \\
2.4 \\
6.3 \\
.9 \\
46.6 \\
8.5\end{array}$ \\
\hline Total & 100.0 & 100.0 & \multicolumn{2}{|c|}{100.0} & 100.0 & 100.0 \\
\hline
\end{tabular}


13. Reasons cited for opinions of credit insurance, within groups of respondents, 2001

Percent

\begin{tabular}{|c|c|c|c|}
\hline \multirow{2}{*}{ Reason' } & \multicolumn{2}{|c|}{ Any closed.end crutit } & \multirow{2}{*}{$\begin{array}{c}\text { No closed-end credit } \\
\text { No insurance }\end{array}$} \\
\hline & Insurance & No insurance & \\
\hline \multicolumn{4}{|l|}{ 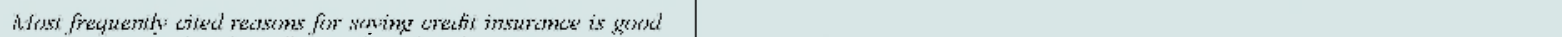 } \\
\hline & $\begin{array}{r}74.0 \\
97\end{array}$ & $\begin{array}{r}77.0 \\
7.5\end{array}$ & $\begin{array}{r}75.6 \\
9.4\end{array}$ \\
\hline & $\begin{array}{l}9.7 \\
6.7\end{array}$ & $\begin{array}{l}7.5 \\
8.9\end{array}$ & $\begin{array}{l}9.4 \\
9.4\end{array}$ \\
\hline 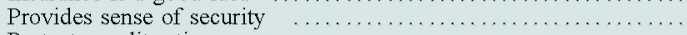 & 4.1 & + & + \\
\hline Protects credit rating $\ldots .$. & 4.5 & $*$ & $*$ \\
\hline 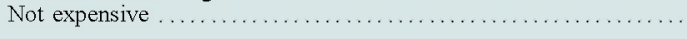 & $*$ & 4.2 & $*$ \\
\hline \multicolumn{4}{|l|}{ Meast firezrentity cited reasons for saying credit inswrance is bal? } \\
\hline Too expensive & $\approx$ & 40.3 & 46.7 \\
\hline 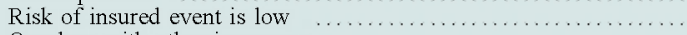 & $\operatorname{sos}$ & 21.6 & 27.7 \\
\hline 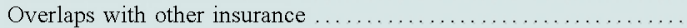 & $\approx s$ & 3.1 & 4.3 \\
\hline Too profitable for insurer $\ldots .$. & \%s & 4.7 & 3.7 \\
\hline Debt is a bad idea $\ldots \ldots \ldots \ldots \ldots \ldots \ldots \ldots \ldots \ldots \ldots \ldots$ & $\approx \approx$ & 21.8 & 9.5 \\
\hline Insurance is a bad idea (not further specified why) . . & $\approx \approx$ & 6.7 & * \\
\hline Not needed if there are no survivors $\ldots \ldots \ldots \ldots \ldots \ldots \ldots$ & soss & * & 4.3 \\
\hline Survivors would be better off selling property instead $\ldots$. & $\approx$ & $*$ & 3.9 \\
\hline
\end{tabular}

insurance. Those who had favorable perceptions of it tended to focus on the security or sense of security it provides, while those who had unfavorable perceptions tended to focus more on the cost and the absence of any need, on their part, for more insurance (table 13).

The survey also asked respondents for their opinions concerning the usefulness of the Truth in Lending disclosure they received at loan closing. The introductory question regarding this topic asked, "The federal Truth in Lending Act now requires that lenders and creditors give consumers a written statement of credit costs, including costs of credit insurance. Did you receive such a statement on this loan?" All those recalling such a statement (about 58 percent of those with credit insurance) were then asked whether they kept the statement and whether the information about credit insurance was helpful in any way.

Among those recalling that they received the Truth in Lending statement, 86 percent said they saved it, and 61 percent said it was helpful. About 27 percent said the statement was not helpful, and 12 percent were not sure (percentages not in a table). Among those who said that the statement was helpful, the reasons indicated most frequently were that it explained the coverages in more detail (mentioned by 39 percent) or that it served as a useful reference (mentioned by about 18 percent).

Some final questions in the 2001 survey reveal a few more details about the purchase of credit-related insurance and the viewpoints of purchasers of insurance on the various credit products. About 45 percent of purchasers of insurance on either first-mortgage or installment credit indicated that the product was offered at the time of the credit application; most of the rest said that it was offered after the credit was approved, and a few respondents did not recall the time of offer (first panel of table 14). The correspond-

14. Distribution of timing of credit insurance transactions and satisfaction with credit insurance, by type of credit, 2001

Percent

\begin{tabular}{|c|c|c|c|}
\hline $\begin{array}{l}\text { Question and } \\
\text { response }\end{array}$ & Mortgage & $\begin{array}{c}\text { Junior } \\
\text { mortgage } \\
\text { HELC }\end{array}$ & $\begin{array}{l}\text { Installment } \\
\text { credit }\end{array}$ \\
\hline When offered? & & & \\
\hline At application & 45.3 & 61.9 & 42.3 \\
\hline After approval $\quad . \ldots$. & 23.0 & 30.9 & 37.2 \\
\hline $\begin{array}{l}\text { After loan documents } \\
\text { signed }\end{array}$ & 243 & 3.1 & 115 \\
\hline Self initiated $\ldots \ldots \ldots$ & 1.0 & $*$ & $\approx$ \\
\hline $\begin{array}{l}\text { Do not know/Decline } \\
\text { to answer }\end{array}$ & 6.4 & 4.1 & 9.0 \\
\hline Total & 100.0 & 100.0 & 100.0 \\
\hline Satisfied? & & & \\
\hline Very .............. & 25.8 & 50.0 & 26.9 \\
\hline $\begin{array}{l}\text { Somewhat } \\
\text { Neither satisfied }\end{array}$ & 56.5 & 33.3 & 63.5 \\
\hline $\begin{array}{l}\text { nor dissatisfied } \\
\text { Somewhat dissatisfied }\end{array}$ & $\begin{array}{r}11.3 \\
1.6\end{array}$ & $\begin{array}{r}11.1 \\
5.6\end{array}$ & $\begin{array}{l}3.8 \\
2.6\end{array}$ \\
\hline Very dissatisfied .... & $\approx$ & $*$ & $s$ \\
\hline $\begin{array}{l}\text { Do not know/Decline } \\
\text { to answer }\end{array}$ & 4.8 & * & 3.2 \\
\hline Total & 100.0 & 100.0 & 100.0 \\
\hline Purchase again?" & & & \\
\hline & 71.0 & 77.8 & 94.2 \\
\hline $\begin{array}{l}\text { No } \\
\text { Do not know/Decline }\end{array}$ & 24.2 & 22.2 & 5.8 \\
\hline to Answer ........ & 4.8 & $*$ & $*$ \\
\hline Total & 100.0 & 100.0 & 100.0 \\
\hline
\end{tabular}

Note. Components may not sum to 100 because of rounding.

1. Opinions concerning whether users of installment credit would purchase credit insurance again, reported in table 11, are repeated here for completeness and ease of comparison

* I.tss thin i..5 peteint.

SoURCE. Surveys of Consumers. 
ing proportions among the smaller number of juniorlien credit users were a bit different: A somewhat higher proportion recalled that the offer was made at the application. Regardless of when the insurance was offered, more than 80 percent of each group of credit users reported current satisfaction with the specific credit-insurance product purchased, with the fraction reaching 90 percent among installment credit users (second panel of table 14).

Finally, the proportion that indicated a willingness to purchase credit insurance again was also high among current purchasers in each group of credit users, although it was lower among mortgage credit users than among those with installment credit (third panel of table 14). As with the other attitude measures, the willingness of users of credit insurance to repurchase it seems to indicate that they feel considerably better about the product than its critics.

\section{CONCLUSION}

Conclusively evaluating the direct effects of disclosure legislation like Truth in Lending on either consumer behavior or the functioning of the credit marketplace is never a simple matter because there are always competing explanations for observed phenomena. From consumer surveys over time, however, it seems likely that disclosures required by Truth in Lending have had a favorable effect on the ready availability of information on credit transactions. There are no corresponding measurements for the years before Truth in Lending, but it is difficult to imagine that two-thirds or more of credit users would have reported in those years that obtaining credit information was "somewhat easy" or "very easy." Furthermore, the pricing information that consumers most often report they want is precisely the items the required disclosures emphasize.

Although it seems unlikely that consumers spend a great deal of time thinking about information condi- tions in consumer credit markets, they do not appear to have widespread complaints either. They seem mostly satisfied with recent credit experiences, and they believe that Truth in Lending makes people more confident when dealing with creditors. This is not to say that required disclosures could not be improved. Aside from whether disclosures might help consumers more by focusing on some different concept of credit cost, an issue not discussed in this article, some changes in timing of the disclosures might benefit consumers. Consumers also report in the surveys that disclosures might be clearer. The survey results suggest that much of consumers' dissatisfaction with credit information is based more on a desire for clarity and simplification than on a demand for more information. Views about the situation of other consumers, however, are less favorable; many respondents seem to think that other consumers do need more information.

There are, of course, some remaining problems in consumer credit markets. The surveys seem to indicate that most consumers have benefited from the ready availability of credit cost disclosures, but anecdotal reports that abusive practices still affect some consumers suggest the need for improvements in financial literacy and for appropriate enforcement efforts against remaining illegal practices.

The relative consistency of responses to the lines of questioning in these surveys is heartening in that there does not seem to be evidence of a view that the credit information situation has worsened over time, despite more complicated consumer credit products and more widespread credit use. With respect to credit insurance, because the views of users and nonusers seem so divergent, it seems important that the views of users be given sufficient weight in considering public policies in this area. According to the views expressed by many users of credit insurance, eliminating this product by regulation could be disadvantageous to them. 